\title{
Effect of Nurse Therapeutic Communication on Patient Satisfaction in the Installation of Genreral Hospital in Massenrempulu, Enrekang District
}

\author{
${ }^{1}$ Indri Primadianty, ${ }^{2}$ Indar , ${ }^{4}$ Alwi Arifin, ${ }^{5}$ Amran Razak \\ 1, 2,4,5 Administrative and Policy Department \\ Faculty of Public Health Hasanuddin University Makassar, Indonesia
}

\author{
${ }^{3}$ Ummu Salmah \\ ${ }^{3}$ Production Health department, \\ Faculty of Public Health
}

\begin{abstract}
Therapeutic communication is one of the important keys in providing patient services in hospitals. Nurses who have communication skills, not only will easily establish a relationship of trust with patients, also prevent illegal problems, and increase satisfaction in the hospital. This study aims to analyze the effect of nurses' therapeutic communication with patient satisfaction in the inpatient installation at Massenrempulu District Hospital Enrekang. The method used is this research is an observational analytic with cross sectional study design. The population in this study were patients in the inpatient hospital of Massenrempulu District Hospital. The research sample of 75 people. The technique of determining the sample is to use the accidental sampling method. Analysis of the data used is chi square and multiple logistic regression.
\end{abstract}

The results showed that the majority of respondents aged 40-49 years $(25.3 \%)$, were female $(61.3 \%)$, had elementary / equivalent education $(30.7 \%)$ and worked as farmers $(36.0 \%)$. The analysis showed that there was a statistically significant relationship between the variable respect $(0.002)$, positive attitude (0.019) and not a meaningful relationship opening up (0.239) with patient satisfaction. The results of multivariate analysis with multiple logistic regression tests showed that the positive attitude of $\operatorname{Exp}(B)$ or Odds Ratio was 0.595. The most dominant variable influences patient satisfaction in the inpatient installation of Massenrempulu District Hospital, Enrekang Regency.

Keywords:- component; Therapeutic Communication, Satisfaction, Positive Attitude, Opening Up, Respect

\section{INTRODUCTION}

Sustainable Development Goals (SDGs) is a new global development agreement, agreed upon by 193 member states of the United Nations (United Nations) including Indonesia. Indonesia is one of the countries that has an active role in determining the goals and objectives of sustainable development. (Ministry of PPN / Bappenas, 2017).

\author{
${ }^{6}$ Syamsuddin, \\ ${ }^{6}$ Economic Department, Faculty of Economic and Bussiness \\ Hasanuddin University, Makassar, Indonesia
}

The goal of the stunting problem is to end all forms of malnutrition in 2030, including in 2025 reaching internationally agreed targets for short and thin children under 5 years of age, and meeting the nutritional needs of adolescent girls, pregnant and lactating women, and seniors ( Perpres 59, 2017). The internationally agreed target of 2025 is a $40 \%$ reduction in the number of children under 5 years who are stunted (WHO, 2013).

Commitment and capacity of local government is very important in overcoming the problem of stunting, this is appropriate because many countries in Asia and Africa embrace a decentralized political system of government. A decentralized system requires building commitment and capacity at various political and bureaucratic levels where decisions are made and resources are allocated (Gillespie, S, et.al., 2013).

Indonesia is the number 3 (three) country with the highest stunting prevalence in the South-East Asia Region with an average prevalence of stunting toddlers in 20052017 of $36.4 \%$. Indonesia was determined as a country with poor nutritional status by WHO because of the high prevalence of stunting under five in Indonesia. The stunting tolerance limit for a country according to WHO is $20 \%$ or one fifth of the number of children under five (WHO, 2018 in the Ministry of Health, 2018).

The prevalence of stunting toddlers in Indonesia is $30.8 \%$, with very short toddlers $11.5 \%$ and short toddlers $19.3 \%$. The province of East Nusa Tenggara is the province with the highest stunting of under five children by $42.6 \%$ and the lowest is DKI Jakarta by $17.7 \%$. In Indonesia, South Sulawesi Province was in the fourth highest number of stunting sufferers reaching 35.6\%, and Enrekang District had the highest stunting sufferer in South Sulawesi Province by $42.7 \%$ in 2018 (Riskesdas, 2018). Enrekang Regency is also one of the 100 priority districts / cities for stunting prevention in 2018 (TNP2K, 2018).

The food and nutrition community agrees that building political commitment is crucial to advancing food security and nutrition on the government's agenda (Fox, et.al, 2014). Creating environmental conditions that allow 
for the reduction of malnutrition including how to create policy and political momentum, and change momentum be implementation and impact (Harris, J. et.al, 2017).

Indonesia is ranked 10th out of 45 countries related to the Hunger and Nutrition Commitment Index (HANCI). Indonesia is ranked 10th in terms of commitments to address nutrition issues / Nutrition Commitment Index (NCI) and ranked 17th for commitments to reduce hunger (HRCI). From the survey results, Indonesia is categorized as a country with a high percentage of stunting toddlers (30-39\%) but only has the same middle-ranking political commitment with Mali. In addition there are 2 indicators out of 12 indicators of government commitment to address nutritional problems that have very low scores, namely on the indicator of sanitation access and indicators of nutritional features in national development policies are still weak (Te lintelo, et.al., 2015).

Research on political commitments carried out in East Nusa Tenggara Province shows that verbal commitment and local government institutions are already good but still low on budget commitments (Bre Boli, Elisabeth, et al, 2018). Lack of budget commitment is also the result of research conducted in North Bengkulu Regency, other indicators that have not yet been achieved are the promotion of exclusive breastfeeding, sanitation coverage (healthy latrines), visits to pregnant women namely $\mathrm{K} 1$ and $\mathrm{K} 4$ and legal indicators (Rozi \& Novega, 2018).

The purpose of this study was to determine the political commitment of the Enrekang Regency Government in overcoming the problem of stunting to realize the Sustainable Development Goals.

\section{MATERIALS AND METHODS}

\section{A. Location and Research Design}

This research was conducted in Enrekang Regency, South Sulawesi Province. This research is a qualitative research with a case study approach.

\section{B. Population and Sample}

Population are government officials in the Enrekang Regency government scope who have the authority and are directly involved in policy making and implementing stunting problem handling activities. The informants of this study were 11 people who were selected by purposive sampling.

\section{Data Types and Sources}

Data collection was obtained by means of in-depth interviews with informants, document review and observation.

\section{Data analysis}

Stages of data analysis in this study are: organize and prepare data for analysis, read or see all data, data coding, description, narration and interpretation. Data validity is done by the triangulation method.

\section{RESULTS}

\section{A. Characteristics of Informants}

Policy (stunting handling program in regional development planning documents)

Stunting handling activities have been included in the Regional Medium-Term Development Plan (RPJMD) document in Enrekang District by making the percentage of stunting reduction the main indicator in the 2018-2023 RPJMD. The initial target of the RPJMD was $45.8 \%$ with the target of achievement in 2023 being $19.5 \%$ with a reduction in the percentage of stunting prevalence of $26.3 \%$ for 5 years or an average of $5.26 \%$ per year.

Excerpts from interviews regarding stunting activities in the Regional Medium-Term Development Plan (RPJMD):

(US, 40 years old) "The issue of stunting is a priority for Enrekang Regency ... because it has become an indicator in the RPJMD"

(RD, 48 years old) "In the RPJMD the indicator is in the form of a percentage reduction in stunting per year from 2019-2023"

Stunting management activities have also been adopted in the 2018-2023 Health Service Strategic Plan (Renstra) which refers to the taget found in the SDGs. In addition, supporting activities to accelerate the reduction of stunting have also been accommodated in the 2018-2023 Health Office Strategic Plan, namely: health services for pregnant women, infant and toddler health services, exclusive breastfeeding for infants, promotion of behavior change, access to proper sanitation, use of latrines and access to clean water. The following are the results of the interview informant:

\section{(ST, $53 \mathrm{Th}$ )}

"In the Health Office Strategic Plan there are already special activities for stunting support activities for stunting in the health department include maternal child health, poor nutrition, immunization, exclusive breastfeeding, JKN, adolescent health, health promotion, clean water and sanitation"

\section{(H 42 years old)}

"There are several sections in the health office the activities and indicators are in the health department strategic plan such as under nutrition health services for malnourished children, health services for pregnant women, children under five, exclusive breastfeeding, immunization, infectious diseases, health promotion, clean water and sanitation"

In addition to the Health Service in the Department of Food Security activities and indicators of stunting support activities have also been adopted into the 2018-2023 Strategic Plan and referring to the target SDGs. Indicators at the Food Security Service are population travel with moderate or severe food insecurity, based on the scale of 
experience of food insecurity and increasing access to nutritious food. The following are the results of the interview informant:

(SY, 55 years old) "In the strategic plan of food security activities that are in nature support the acceleration of stunting reduction we include in the 20182023 strategic plan"

\section{B. The budget}

The special budget for stunting activities has been budgeted in the district budget. Enrekang in 2019 and 2020. The budget contained in the 2019 budget year health service amounted to Rp.70,000,000, and in 2020 amounted to Rp.70,000,000. The stunting budget allocation is specifically only budgeted in the APBD starting in 2019, in the 2018 APBD there is no budget allocated specifically for stunting activities.

In addition to the Department of Health in BappedaLitbang there is a budget to coordinate the preparation of a stunting Regional Action Plan (RAD) in 2019 of Rp.88,000,000 and in 2020 of Rp. 145,600,000. In the social service, there is a budget for monitoring the provision of assistance in fulfilling nutritional stunting in the 2020 budget year of Rp. 30,000,000, the budget is used to assist the distribution of PKH funds (family hopes program) which is prioritized for underprivileged families who have pregnant women or stunting toddlers. In the Department of Population and Family Planning in 2020 there is a budget for socialization activities to prevent stunting for children in the first 1000 days of life in the amount of Rp. 30,000,000. The following are the results of the interview respondent:

"The budget is in the DHO, Diknas, Bappeda, population control and family planning, the number ... I don't memorize it ... later, just look at the APBD ... the budget for stunting there is a source of funds from the $A P B D$ and some from the APBN (DAK) and village funds"

\section{(RD, $48 \mathrm{Th})$}

"The budget is in the health department, the ministry of education, the national planning agency, food security, the district government office, the social ministry ... overall I don't remember ... besides the APBD, the APBN, the stunting budget can also use village funds"

Based on the results of interviews with informants it is known that PKK activities are directed to support stunting prevention efforts even though the PKK budget is not specifically mentioned intended for stunting activities. The PKK budget for 2019 is $800,000,000$ and 2020 is $796,400,000$. The following are the results of the interview excerpt:

(RD, 48 years old) "Because it is not a nomenclature of activities so the name of the activity does not specifically mention stunting, but its activity is to support the acceleration of stunting reduction for example in PKK activities"
(KR, $40 \mathrm{Th})$

"The total budget is 70 million for stunting ... a separate stunting budget has existed since 2019"

(HR, $42 \mathrm{Th}$ )

"The stunting budget in particular has been budgeted for 2 years, amounting to 70 million"

(RD, $48 \mathrm{Th}$ )

"If there are 145 million in Bappeda for stunting coordination ... in the main OPD which is directly related to stunting prevention and control ... the amount can be seen in the regional budget"

In addition to the special budget for stunting, the budget allocation for supporting and supporting activities to accelerate stunting reduction and stunting prevention has also been budgeted in the Enrekang Regency APBD. In 2019 the budget will be Rp. 36,442,638,399, this budget is spread across four OPDs, with funding coming from the APBD Kab. Enrekang Rp. 20,882,476,800, DAK funds of Rp. 15,490,161,599 and decon of Rp. 50,000,000. In 2020 the budget of this supporting activity increased by $5.5 \%$ to $38,448,555,854$. The 2020 budget is sourced from the District Budget. Enrekang amounting to Rp.21,059,816,864, DAK funds amounting to Rp.17,388,738,990.

The budget allocation for stunting is also found in the village funds, namely in 10 villages locus stunting, the 2019 budget is Rp.98,755,000, while the health budget is Rp.446,747,975. In general, the activities carried out are information dissemination and counseling related to stunting and supplementary feeding to pregnant women and toddlers. Following are the results of the interview excerpts related to the budget of supporting stunting activities:

\section{DISCUSSION}

\section{$>$ Policy (stunting handling program in development planning documents).}

According to Te Lintelo, et.al. (2013) that one form of government commitment in dealing with nutrition problems is the existence of government programs or policies related to nutrition. Government programs and policies on nutrition are the extent to which nutrition programs / activities are contained in national and regional development policy / strategy documents.

Based on the results of research on commitment policies (policies) show that the Enrekang District Government has a good commitment because it has included indicators and stunting activities and other supporting activities in the regional development policy documents namely RPJMD, RKPD, Renstra and Renja. The results of this study are in line with research in Tanzania that nutrition programs have been integrated into national multisectoral and independent policy plans and strategies. Specific indicators have also been included in the national development plan and vision of 2025 on national strategies for increasing growth and poverty reduction (Te Lintelo, et al. 2020). 
The same results in the research of Fransiska, Rozi and Novega (2018) in North Bengkulu showed that nutrition- related programs had become a priority and had been included in regional development documents, although there were no specific stunting activities. The results of this study differ from the results of research in Padang Pariaman that the government's commitment related to the stunting program in regional development policies is still weak (Syafrina, Merri, et al. 2019).

Activities and supporting indicators for stunting have also been included in the strategic planning documents of the Health Office and the Office of Food Security, this is in line with research in Bangladesh which shows that several programs and activities.

Determining the success of stunting reduction programs in the country are food security and food diversity, maternal and child health, water and sanitation, income, poverty and inequality, gender and women's empowerment, policies and nutritional drivers (Nisbett, Nicholas, et.al. 2017 ).

Also based on the results of research from Beal, Ty. et.al (2018) that the determinants of stunting in Indonesia are non- exclusive breastfeeding during the first 6 months, low socioeconomic status of the household, premature birth, newborn body length, maternal education level, quality of latrines and clean water, environment, low access to health services, community culture, agriculture and the food system.

The stunting targets contained in the SDGs, goal 2 are: by 2030, eliminating all forms of malnutrition, including by 2025 achieving internationally agreed targets for short and thin children under 5 years of age, and meeting the nutritional needs of adolescent girls, mothers pregnant and breastfeeding, and seniors (Bappenas, 2017). The internationally agreed target of 2025 is a $40 \%$ reduction in the number of children under 5 years who are stunted (WHO, 2013).

Comparison between Enrekang District Government's target achievement in 2023 of $19.5 \%$ with the target of reducing the prevalence of stunting contained in SDGs. By using 2018 riskesdas data of $42.7 \%$ (a decrease of 40\%), the target of SDGs in 2025 is $17.08 \%$. There is still a difference of $2.42 \%$ of the target that the Enrekang Regency government must achieve within two years. If the estimated RPJMD target for 2023 is reached, the stunting reduction in accordance with the SDGs target in 2025 can be achieved by the Enrekang Regency government.

\section{$>$ The budget}

Based on the results of this study it is known that the Enrekang District Government has a fairly good commitment in terms of budget allocation to overcome the problem of stunting. The Government of Enrekang Regency in 2019 has allocated a budget from the APBD of Rp. 158,000,000 for stunting-specific activities, this budget is spread across two DPOs, namely the Health Office and Bappeda - Litbang, and in 2020 the budget has increased by $74 \%$ to Rp.275,600,000 spread across four DPOs, namely the Health Office, Bappeda Research and Development, Social Services and Population and KB Control Services

In addition, supporting activities and those directly related to the causes of stunting have also received budget allocations in the Enrekang Regency APBD. In 2019 the budget will be Rp. 36,442,638,399, this budget is spread across four OPDs, with funding coming from the APBD Kab. Enrekang Rp. 20,882,476,800, DAK funds of Rp. $15,490,161,599$ and decon of Rp. 50,000,000. In 2020 the budget of this supporting activity increased by $5.5 \%$ to $38,448,555,854$. The 2020 budget is sourced from the District Budget. Enrekang amounting to Rp.21,059,816,864, DAK funds amounting to Rp.17,388,738,990.

The results of this study are in line with the research of Te Lintelo, et al. (2020) in Tanzania which shows that the nutrition budget allocation per district / city increased from 58 million TZS in 2011/2012 to 217 million TZS in $2014 / 2015$. In addition the president's office for local government increased the allocation of mandatory minimum nutrition funding per child from TZS 500 in $2016 / 2017$ to TZS 1000 in 2017/2018. The Tanzanian government doubled spending to TZS 11 billion in 2017 for local government support for infants, mothers, young children and adolescent nutrition.

Different results were obtained in studies conducted in Padang Pariman District, North Bengkulu and East Nusa Tenggara Province which showed that the government's commitment regarding budget allocation for stunting activities was still low (Syafrina, Merri., Et al. 2019; Fransiska Rozi \& Novega. 2018; Bre Boli, E., et al. 2018).

Although the commitment of the Enrekang Regency government related to the budget is quite good, but the commitment of institutions (OPD) is still not good, this is seen from the fact that there are only a few OPDs that budget for stunting activities, only six OPDs have budgeted special stunting activities and stunting support activities. This is not in accordance with the Decree of the Regent regarding the establishment of an agreed stunting and integrity pact working group. In the regent's decree, it was stated that there were 18 main OPDs that synergized and cooperated in efforts to reduce stunting. Each OPD stunting intervention in accordance with their respective authorities, and costs incurred due to the implementation of the stunting intervention are charged to the DPA of each OPD.

The 10 stunting priority villages of $2.8 \%$ were allocated to the health budget of Rp.446,747,975, while for specific stunting activities of $0.6 \%$ or Rp.98,755,000 in the form of supplementary feeding for pregnant women and toddlers and socialization stunting. In addition to the Village Minister Regulation and Enrekang Regent Regulation, the use of village funds related to stunting is 
also regulated in Minister of Finance regulation Number. 205 / PMK.07 / 2019, Article 24 paragraph 1 states that one of the conditions for disbursement village budget phase III is to attach a report on village level stunting convergence of the previous fiscal year. Based on the budget sources for handling stunting in Enrekang District, it can be seen that in addition to the commitment of the Enrekang Regency government which is quite good, the commitment of the central government can be seen from the DAK / APBN budget allocation and the allocation of village funds for stunting handling. This is in line with the convergence of stunting handling efforts that will be realized if national, regional, and village programs / activities as providers of specific nutrition and sensitive nutrition intervention services are carried out in an integrated and integrated manner in accordance with their respective authorities. (TNP2K \& Indonesian Vice President Secretariat, 2018).

In general, the budget allocation in Enrekang Regency is expected to reduce the stunting prevalence rate in accordance with the goals of SDGs in 2030 zero stunting and to reduce stunting by $40 \%$ in 2025 . Research conducted by Shekar, Meera. et.al (2017) related to an increase in the annual fee scale for the period 2016 - 2025 carried out in 37 countries with a high prevalence of stunting including Indonesia. This research focuses on a package of specific nutritional interventions that have proven to be effective. The results of this study indicate that the need for a 10-year budget to increase specific nutrition interventions by 49.5 billion dollars, to achieve this target financing must now increase from 2.6 billion dollars to 7.4 billion dollars on average per year. Achieving a stunting target is feasible but will require large and coordinated investment in a supportive environment.

\section{CONCLUSIONS AND RECOMENDATION}

The Enrekang District Government has good policy commitments in handling stunting issues. This can be seen from the adoption of indicators and stunting activities as well as indicators and activities related to stunting in local government documents, namely RPJMD and RKPD districts and Strategic Plans and Renja of the Office of Health and Food Security. In addition, the indicators contained in the RPJMD and Strategic Plan have referred to and are aimed at achieving the SDGs targets in 2025 and 2030 .

The budget commitment of the Enrekang Regency government in handling the stunting problem is quite good, because the budget allocation for handling stunting has increased 74\% from 2019 amounting to Rp.158,000,000 to Rp.275,600,000 in 2020. Besides that the budget allocation for supporting stunting activities increased 5, 5\% from 2019 amounting to $36,442,638,399$ to Rp. $38,448,555,854$ sourced from APBD, DAK and Deconcentration funds. In addition to funding from the APBD, village funds in 10 stunting locus villages also included a budget allocation for the stunting reduction convergence program of $\mathrm{Rp}$. $98,755,000$ in 2019.
Even though the overall commitment related to the budget is good enough but the institutional commitment is still weak. This can be seen in only 6 DPOs out of 18 DPOs that have stunting budgets and special stunting activities and support activities, so that the Enrekang District Government needs to strengthen institutional commitment in terms of budget allocation for convergence / intervention activities to reduce stunting. Enrekang District Government needs to strengthen commitment / cooperation across sectors in the implementation of stunting handling activities.

\section{REFERENCES}

[1]. Beal, Ty., Tumillowicz, A., Sutrisna, A., Izwardy, D., Neufeld, L.M. (2018) A review of child stunting determinants in Indonesia. John Wiley \& Sons, Ltd. 14(4), 1-10.

[2]. BreBoli E., Baliwati Y.F., \& Sukandar D. (2018). Komitmen Politik dan Peluang Pengembangan Kebijakan Gizi Pemerintah Daerah Provinsi Nusa Tenggara Timur. JURNAL MKMI, Vol. 14. 351-359.

[3]. Fox A. M., Balarajan, Y., Cheng, C., \& Reich, M.R. (2014) Measuring political commitment and opportunities to advance food and nutrition security: piloting a rapid assessment tool. Health Policy and Planning, 30.566-578.

[4]. Gillespie S., Haddad L., Mannar V., Menon P., Nisbett N., \& and the Maternal and Child Nutrition Study Group. (2013) The politics of reducing malnutrition: building commitment and accelerating progress (Maternal and Child Nutrition 4).TheLancet. http://dx.doi.org/10.1016/S0140-6736(13)60842-9.

[5]. Harris J., Drimie S., Roopnarainec T., \& Covica N. (2017). From coherence towards commitment: Changes and challenges in Zambia's nutrition policy environment. journal homepage: www.elsevier.com/locate/gfs, Global Food Security. 13.49-56.

[6]. Kementerian Perencanaan Pembangunan Nasional /Bappenas. (2017) RINGKASAN METADATA INDIKATOR TUJUAN

PEMBANGUNAN BERKELANJUTAN (TPB)/ SUSTAINABLE DEVELOPMENT GOALS (SDGs). Jakarta

[7]. Kementerian Kesehatan. (2018). Buletin stunting (Situasi Balita Pendek/stunting di Indonesia). Pusat Data dan Informasi kementerian Kesehatan Republik Indonesia.

[8]. Kementerian Kesehatan. (2019). Laporan Nasional, RISKESDAS 2018. Badan Penelitian dan Pengembangan Kesehatan. Jakarta.

[9]. Nisbett N., Davis P., Yosef S., \& Akhtar N. (2017). Bangladesh's story of change in nutrition: Strong improvements in basic and underlying determinants with an unfinished agenda for direct community level support. Elsevier. Global Food Security. 13. 21-29 
[10]. Republik Indonesia, Peraturan Menteri Keuangan Republik Indonesia Nomor 205/PMK.07/2019 tentang Pengelolaan Dana Desa.

[11]. Rozy V.F. \& Novega. (2018). ANALISIS PERMASALAHAN GIZI BURUK BERDASARKAN INDIKATOR NUTRITION COMMITMENT INDEX (NCI) DI KABUPATEN BENGKULU UTARA.An-Nadaa. 5863

[12]. Shekar Meera. et.al. (2017). Reaching the global target to reduce stunting: an investment framework. Oxford. Health Policy and Planning. 32. 657-668.

[13]. Syafrina, M., Masrul., Firdawati. (2019) Analisis Komitmen Pemerintah Kabupaten Padang Pariaman dalam Mengatasi Masalah Stunting Berdasarkan Nutrition Commitment Index 2018. Jurnal kesehatan Andalas. 8 (2), 233-244

[14]. Te Lintelo D. J. H., Haddad L.J., Lakshman R., \& Gattelier K. (2013). The Hunger And Nutrition Commitment Index (HANCI 2012) Measuring the Political Commitment to Reduce Hunger and Undernutrition in Developing Countries. Institute of Development Studies UK.

[15]. Te Lintelo, D.J.H. \& Lakshman, R. W. D. (2015) Equate and Conflate: Political Commitment to Hunger and Undernutrition Reduction in Five High-Burden Countries. www. elsevier.com. World Development Vol. 76, 280-292.

[16]. Te Lintelo D. J.H., Page P., Kaganda J., \& Esau D. (2020). Tanzania's story of change in nutrition: Political commitment, innovation and shrinking political space. Elsevier. Global Food Security. 24. 100350.

[17]. TNP2K, Kementerian Koordinator Bidang Pembangunan Manusia dan Kebudayaan, Kementerian PPN/Bappenas. (2018).160 Kabupaten/Kota Prioritas Dengan Masing-masing 10 Desa Untuk Penanganan Stunting (Kerdil). Jakarta

[18]. TNP2K, Sekretariat Wakil Presiden Republik Indonesia. (2018). Panduan Konvergensi Program/Kegiatan Percepatan Pencegahan Stunting (Buku Pegangangan Resmi Organisasi Perangkat Daerah). Jakarta.

[19]. World Health Organization. (2013). Global Nutrition Policy Review :What does it take to scale up nutrition action?. Geneva,Switzerland. 